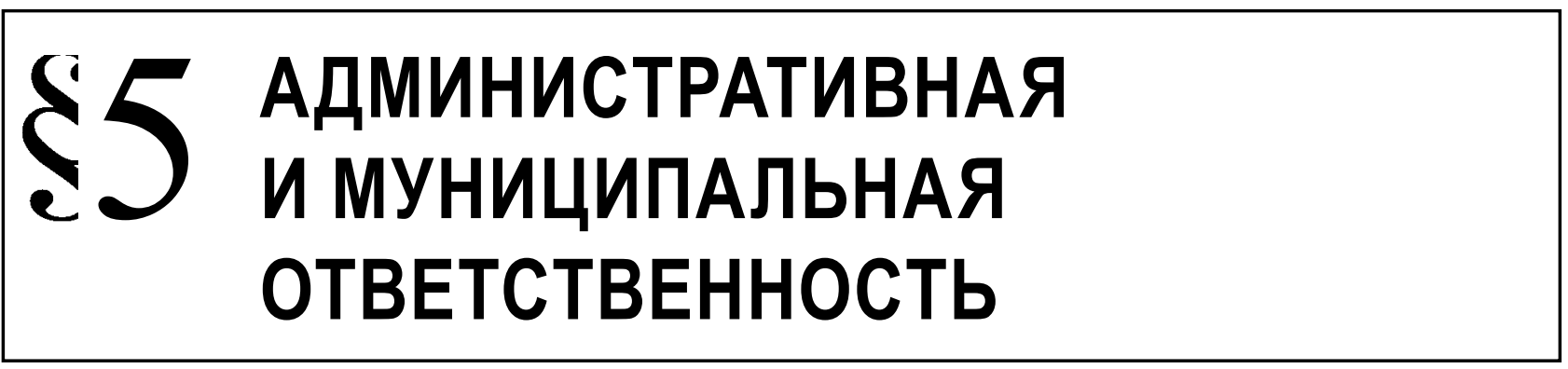

Кулаков Н.А.

\title{
ГАРМОНИЗАЦИЯ ГРАЖДАНСКОГО ЗАКОНОДАТЕЛЬСТВА И ЗАКОНОДАТЕЛЬСТВА ОБ АДМИНИСТРАТИВНОЙ ОТВЕТСТВЕННОСТИ В ОБЛАСТИ ОХРАНЫ АВТОРСКИХ И СМЕЖНЫХ ПРАВ
}

Аннотация. Статья посвящена исследованию проблем административной ответственности в области авторских и смежных прав, правовые основы которой характеризуются наличием некоторой внутренней несогласованности и нуждаются в корректировке. Предметом исследования выступает совокупность основных нормативных правовых актов, регулирующих вопросы охраны и защиты авторских и смежных прав в Российской Федерации. Цель исследования - провести сравнительно-правовой анализ норм гражданского и административного законодательства в указанной области, а также выработать ряд предложений по гармонизации указанных норм. Методологической основой исследования являются диалектический метод научного познания, формально-логический, сравнительно-правовой, системно-функциональный и другие частные методы научно-исследовательской работы. В результате проведенного исследования автор приходит к выводу о том, что норма об административной ответственности в области авторских и смежных прав нуждается в гармонизации с гражданским законодательством. По итогам исследования в статье формулируется ряд предложений по внесению изменений в законодательство об административной ответственности, которые, по мнению автора, будут способствовать повышению эфрективности административно-правовой охраны интеллектуальной собственности.

Ключевые слова: административное принуждение, административная ответственность, интеллектуальная собственность, интеллектуальные права, исключительные права, авторские права, смежные права, информация, экземпляры произведений, фонограмма.

Abstract. The paper is devoted to the study of the problems of administrative liability in the sphere of copyright and related rights protection, whose legal grounds are characterized by a certain internal inconsistence and need correction. The research subject is the set of general statutory instruments regulating the issues of copyright and related rights protection in the Russian Federation. The purpose of the research is the comparative-legal analysis of the provision of civil and administrative legislation in the mentioned sphere, and the development of the proposals about harmonization of the mentioned provisions. The research methodology is based on the dialectical method of scientific cognition, the formal-logical, comparative-legal, system and functional and other specific research methods. The author concludes that the provision about administrative liability in the sphere of copyright and related rights protection needs harmonization with civil legislation. The author formulates the proposals about introducing changes in administrative liability legislation which, in the author's opinion, will promote improvement of the effectiveness of copyright and related rights administrative protection.

Key words: sound record, copies of works, information, related rights, copyright, exclusive rights, intellectual property rights, intellectual property, administrative liability, administrative coercion.

$\mathrm{B}$ жным показателем уровня нравственного развития общества является признание за субъектами интеллектуально-творческой деятельности интеллектуальных прав. Кроме того, не секрет, что эффективная правовая охрана интеллектуальной собственности является одним из ключевых факторов экономического прогресса. В связи с этим российское государство уделяет значительное внимание правовому регулированию общественных отношений, связанных с созданием и охраной интеллектуальной собственности.

Право интеллектуальной собственности преимущественно урегулировано частью четвертой Гражданского кодекса Российской Федерации 
(далее - ГК РФ) [1]. Не случайно в юридической литературе именно этот нормативный правовой акт, образно характеризуют как конституцию интеллектуальной собственности [2]. Гражданское законодательство определяет перечень объектов интеллектуальных прав, правовые основы возникновения, изменения, прекращения этих прав. Также в ГК РФ определены способы их гражданскоправовой защиты. Наряду с этим, российское законодательство предусматривает и иные способы защиты интеллектуальных прав. В частности, одним из таких способов является административная ответственность за нарушение авторских и смежных прав, предусмотренная ч. 1 ст. 7.12 КоАП РФ [3].

Следует отметить, что право интеллектуальной собственности, согласно позиции ведущих исследователей является комплексным институтом. Регулирование общественных отношений в области интеллектуальной собственности не представляется возможным на основе исключительно гражданского права. Все более очевидным становится то, что в отрыве от норм других отраслей гражданско-правовые механизмы не в состоянии обеспечить необходимую правовую основу для решения многообразных проблем в области интеллектуальной собственности [4]. Об актуальности применения мер административного принуждения неоднократно высказывались многие специалисты в области охраны интеллектуальной собственности [5];[6].

На наш взгляд, административная ответственность, как способ защиты интеллектуальных прав, содержит в себе значительный потенциал. Качественными преимуществами административной ответственности по сравнению с иными способами защиты интеллектуальных прав является, в частности, оперативность и относительно простая процессуальная форма, о чем мы неоднократно говорили ранее [7]; [8].

Административная ответственность позволяет в короткие сроки принять превентивные меры по пресечению действий, нарушающих законные интересы правообладателей (например, изъятие вещей и предметов, предусмотренное ст. 27.1 КоАП РФ). Кроме того, результаты применения мер административного принуждения, документированные в установленном порядке, могут быть использованы в качестве доказательств для дальнейшего разбирательства и защиты интеллектуальных прав в гражданско-правовом порядке.

Диспозиция правовой нормы, предусмотренной ч. 1 ст. 7.12 КоАП РФ, является бланкетной и отсылает правоприменителя к гражданскому законодательству. Гражданско-правовой институт авторского права регулирует отношения, возникающие в связи с созданием и использованием про- изведений науки, литературы или искусства [9]. Права, смежные с авторскими (смежные права), являются производными от авторских прав. Перечень объектов смежных прав закреплен в части 1 ст. 1303 ГК РФ. К смежным правам относятся право на исполнение, право на фонограмму, право организаций эфирного и кабельного вещания, право изготовителя базы данных, а также право публикатора [10].

Объективную сторону рассматриваемого состава административного правонарушения можно условно разделить на две части:

- нарушения, связанные с незаконным использованием экземпляров произведений и фонограмм;

- $\quad$ иные нарушения авторских и смежных прав.

Проанализируем первую из перечисленных групп нарушений более детально, разделив ее на две подгруппы:

- ввоз, продажа, сдача в прокат, или иное незаконное использование экземпляров произведений и фонограмм, если эти носители являются контрафактными в соответствии с ч. 4 ст. 1252 ГК РФ;

- аналогичные действия, если на экземплярах произведений и фонограмм указана ложная информация об их изготовителях, о местах их производства, а также об обладателях авторских и смежных прав.

Рассматривая первый из перечисленных способов правонарушения, акцентируем внимание на сущности нарушения исключительного права на произведение или фонограмму. Исключительное право автора произведения подразумевает возможность использования этого произведения любым не противоречащим закону способом. Согласно п. 2 ст. 1270 ГК РФ под использованием произведения следует понимать:

- $\quad$ воспроизведение произведения (то есть изготовление одного или более экземпляра произведения в любой материальной форме, в том числе в форме звуко- или видеозаписи);

- продажа или иное отчуждение оригинала или экземпляров произведения;

- импорт оригинала или экземпляров произведения в целях распространения;

- прокат оригинала или экземпляров произведения и др.

Аналогичные действия с некоторой спецификой предусмотрены в качестве способов использования объектов смежных прав (ст. 1317 ГК РФ, ст. 1324 ГК РФ и др). Любое из действий, предусмотренных соответствующими статьями ГК РФ в качестве способов использования объектов авторских и смежных прав, совершенные без согласия правообладателя, следует рассматривать в качестве нарушения исключительных прав. 


\section{Административное и муниципальное право 7 (103) • 2016}

В соответствии с п. 4 ст. 1252 ГК РФ в случае, когда изготовление, распространение или иное использование, а также импорт, перевозка или хранение материальных носителей, в которых выражены результат интеллектуальной собственности или средство индивидуализации, приводят к нарушению исключительного права на такой результат или на такое средство, такие материальные носители считаются контрафактными.

Ввоз (в ГК РФ используется термин «импорт»), продажа, сдача в прокат или иное незаконное использование экземпляров произведений или фонограмм - это действия, которые приводят к нарушению исключительного права. Совершение указанных действий в отношении экземпляров произведений и фонограмм само по себе влечет приобретение этими материальными носителями признака контрафактности. Таким образом, действующая формулировка диспозиции ч.1 ст. 7.12 КоАП РФ внутренне не логична и содержит дублирующие друга друга элементы. На наш взгляд, в формулировке диспозиции ч. 1 ст. 7.12 КоАП РФ нет необходимости указывать на дополнительный признак предмета правонарушения, связанный с его контрафактностью.

Необходимо обратить внимание также на используемое в формулировке исследуемой правовой нормы словосочетание «незаконное использование» экземпляров произведений и фонограмм. Следует отметить, что часть четвертая ГК РФ не раскрывает содержания данного термина. Более того, в отношении объектов авторских и смежных прав законодатель использует идентичное словосочетание только в одном случае. Речь идет о норме, предусмотренной ч. 1 ст. 1302 ГК РФ, согласно которой суд может принять обеспечительные меры, направленные, в частности на ограничение доступа к материалам, содержащим незаконно используемые произведения. В ряде случаев (в том числе в тексте той же ч.1 ст. 1302 ГК РФ!) гражданское законодательство применяет термин «неправомерное использование» (ст.ст. 1253.1, 1286.1 и др). Очевидно, что термины «незаконное использование» и «неправомерное использование» объектов авторского права используются гражданским законодательством в качестве синонимов для обозначения действий, нарушающих исключительные права. По нашему мнению, формулировку диспозиции правовой нормы, предусматривающей административную ответственность за нарушение авторских и смежных прав, в части определения способа совершения правонарушения представляется целесообразным скорректировать следующим образом: «ввоз, продажа, сдача в прокат и иное нарушение исключительного права на произведение или фонограмму...».

Рассмотрим второй вариант совершения рассматриваемого правонарушения, когда использова- ние экземпляров произведений и фонограмм сопровождаются указанием на них ложной информации об их изготовителях, о местах их производства, а также об обладателях авторских и смежных прав. Данный способ выполнения объективной стороны посягает на установленные гражданским законодательством требования, связанные с указанием на экземплярах произведений или фонограмм информации об авторском или смежном праве.

Согласно ст. 1300 ГК РФ информацией об авторском праве является любая информация, которая идентифицирует произведение, автора или иного правообладателя, либо информация об условиях использования произведения. Удаление или изменение данной информации, а также использование экземпляров произведений, в отношении которых данная информация была удалена без разрешения автора или иного правообладателя, не допускается. В соответствии со ст. 1310 ГК РФ аналогичные требования устанавливаются и для информации о смежном праве. По нашему мнению, данные требования представляют собой дополнительные гражданско-правовые гарантии, направленные на предупреждение нарушений исключительных, неимущественных, а также иных авторских и смежных прав. Как представляется, совершение действий, нарушающих перечисленные требования, не следует рассматривать в качестве действий, посягающих непосредственно на авторские и смежные права. Такие действия нарушают установленные гражданским законодательством правила использования объектов авторских и смежных прав. В связи с этим, в целях гармонизации гражданского и административного законодательства видится целесообразным предусмотреть в КоАП РФ отдельную статью, предусматривающую административную ответственность за использование экземпляров произведений и фонограмм с нарушением требований гражданского законодательства, связанных с указанием информации об авторских и смежных правах.

В завершении еще раз отметим, что одним из способов защиты авторских и смежных прав является административная ответственность. В целях повышения качества правового материала необходимо исключить из диспозиции правовой нормы, предусматривающей административную ответственность за нарушение авторских и смежных прав, указание на дополнительный признак предмета правонарушения, связанный с его контрафактностью. Формулировку диспозиции данной правовой нормы в части определения способа совершения правонарушения представляется целесообразным скорректировать следующим образом: «ввоз, продажа, сдача в прокат и иное нарушение исключительного права на произведение или 
фонограмму...». Кроме того, административную ответственность за нарушение требований гражданского законодательства, связанных с указанием на экземплярах произведений и фонограмм информации об авторских и смежных правах, следует предусмотреть в рамках отдельной правовой нормы в КоАП РФ. Данные изменения, на наш взгляд, будут соответствовать принципу «системности российского законодательства» и способствовать гармонизации гражданского законодательства и законодательства об административной ответственности и, в конечном итоге, повышению эффективности административно-правовой охраны интеллектуальной собственности.

\section{Библиография:}

1. Гражданский кодекс Российской Федерации (часть четвертая) от 18 февраля 2006 г. № 230-Ф3 (с изм. и доп.) // СЗ РФ. 2006. № 52. Ст. 5496.

2. Муравьев С.В. Конституция интеллектуальной собственности // ЭЖ-Юрист. 2006. № 37. С. 56.

3. Кодекс Российской Федерации об административных правонарушениях от 30 декабря 2001 г. № 195-ФЗ (с изм. и доп.) // СЗ РФ. 2002. № 1 (ч. 1). Ст. 1.

4. Близнец И.А. Право интеллектуальной собственности: теоретико-правовое исследование: Автореферат дисс. ... докт. юрид. наук. М., 2003. С. 11.

5. Акимова Н.В. К вопросу об эффективности административно-правовых мер противодействия правонарушениям в области интеллектуальной собственности // Административное и муниципальное право. 2014. № 2. С. 119 - 127.

6. Клейменова М.О. К вопросу об административно-правовом регулировании защиты исключительного права на средства индивидуализации // Административное и муниципальное право. 2014. № 11. С. 122-125.

7. Кулаков Н.А. Административно-правовая охрана прав на селекционные достижения // Право и государство: теория и практика. 2011. № 5. С. 98-101.

8. Кулаков Н.А. Административная ответственность как способ защиты прав на топологии интегральных микросхем. Материалы ежегодной всероссийской научно-практической конференции (Сорокинские чтения). 20 марта 2015 г. С. 71.

9. Гаврилов Э.П., Городов О.А. и др. Комментарий к Гражданскому кодексу Российской Федерации (постатейный). Ч. 4. М.: ТК Велби; изд-во «Проспект», 2012. С. 120.

10. Маковский А.Л. Комментарий к части четвертой Гражданского кодекса Российской Федерации / Под ред. А.Л. Маковского; вступ. сл. В.Ф. Яковлева; Иссл. центр частн. права. М., 2008. С. 275.

11. Войниканис Е.А. Кодификация законодательства и ее особенности в сфере интеллектуальных прав: теоретикоправовые аспекты // Право и политика. 2014. № 11. C. 1643-1646. DOI: 10.7256/1811-9018.2014.11.13319.

12. Плесовских В.Д. Тенденции развития федерального административно-деликтного права и законодательства // Право и политика. 2012. № 12. С. 1990-1994.

13. Маркова О.В. Перспективы правовой защиты интеллектуальной собственности и способы укрепления устойчивого элемента системы правовой защиты интеллектуальной собственности // Политика и Общество. 2012 . № 6. C. $101-106$.

\section{References (transliterated):}

1. Grazhdanskii kodeks Rossiiskoi Federatsii (chast' chetvertaya) ot 18 fevralya 2006 g. № 230-F3 (s izm. i dop.) // SZ RF. 2006. № 52. St. 5496.

2. Murav'ev S.V. Konstitutsiya intellektual'noi sobstvennosti // EZh-Yurist. 2006. № 37. S. 56.

3. Kodeks Rossiiskoi Federatsii ob administrativnykh pravonarusheniyakh ot 30 dekabrya 2001 g. № 195-FZ (s izm. i dop.) // SZ RF. 2002. № 1 (ch. 1). St. 1.

4. Bliznets I.A. Pravo intellektual'noi sobstvennosti: teoretiko-pravovoe issledovanie: Avtoreferat diss. ... dokt. yurid. nauk. M., 2003. S. 11.

5. Akimova N.V. K voprosu ob effektivnosti administrativno-pravovykh mer protivodeistviya pravonarusheniyam $\mathrm{v}$ oblasti intellektual'noi sobstvennosti // Administrativnoe i munitsipal'noe pravo. 2014. № 2. S. 119 - 127.

6. Kleimenova M.O. K voprosu ob administrativno-pravovom regulirovanii zashchity isklyuchitel'nogo prava na sredstva individualizatsii // Administrativnoe i munitsipal'noe pravo. 2014. № 11. S. 122-125.

7. Kulakov N.A. Administrativno-pravovaya okhrana prav na selektsionnye dostizheniya // Pravo i gosudarstvo: teoriya i praktika. 2011. № 5. S. 98-101.

8. Kulakov N.A. Administrativnaya otvetstvennost' kak sposob zashchity prav na topologii integral'nykh mikroskhem. Materialy ezhegodnoi vserossiiskoi nauchno-prakticheskoi konferentsii (Sorokinskie chteniya). 20 marta 2015 g. S. 71.

9. Gavrilov E.P., Gorodov O.A. i dr. Kommentarii k Grazhdanskomu kodeksu Rossiiskoi Federatsii (postateinyi). Ch. 4. M.: TK Velbi; izd-vo «Prospekt», 2012. S. 120.

10. Makovskii A.L. Kommentarii k chasti chetvertoi Grazhdanskogo kodeksa Rossiiskoi Federatsii / Pod red. A.L. Makovskogo; vstup. sl. V.F. Yakovleva; Issl. tsentr chastn. prava. M., 2008. S. 275.

11. Voinikanis E.A. Kodifikatsiya zakonodatel'stvai ee osobennosti vsfere intellektual'nykh prav: teoretiko-pravovye aspekty // Pravo i politika. 2014. № 11. C. 1643-1646. DOI: 10.7256/1811-9018.2014.11.13319.

12. Plesovskikh V.D. Tendentsii razvitiya federal'nogo administrativno-deliktnogo prava i zakonodatel'stva // Pravo i politika. 2012. № 12. C. 1990-1994.

13. Markova O.V. Perspektivy pravovoi zashchity intellektual'noi sobstvennosti i sposoby ukrepleniya ustoichivogo elementa sistemy pravovoi zashchity intellektual'noi sobstvennosti // Politika i Obshchestvo. 2012. № 6. C. 101-106. 